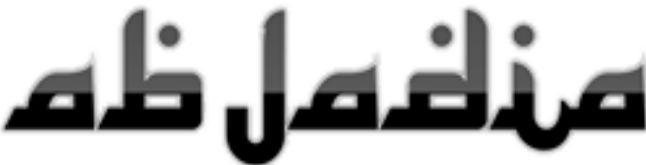 \\ International Journal of Education}



Pi] Publisher

Fakultas Ilmu Tarbiyah dan Keguruan

Universitas Islam Negeri (UIN)

Mualana Malik Ibrahim Malang

Indonesia

(2443-0587 - ISSN Online

居 2528-3979 - ISSN Print

躬 History Article

t) Received : 03-04-2017

(19.8) Reviced : 19-04-2017

目 Accepted : 23-06-2017

\section{doi.org/ 10.18860/abj.v2i1.5310}

http://ejournal.uin-malang.ac.id/index.php/ abjadia/article/view/5310

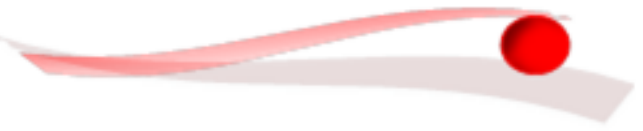

Muhamad Isbah Habibii

9. Indonesia

(3)

Universitas Islam Negeri

Maulana Malik Ibrahim

Malang Indonesia

\section{Corresponding Author}

(C) 085748408778

@ bjhabibi09@gmail.com

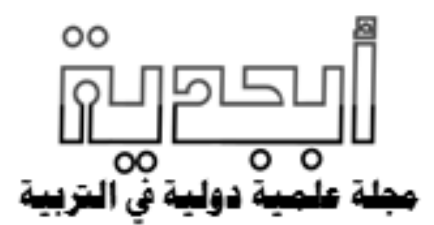

Muhamad Isbah Habibii

Indonesia

$$
\text { تغيرات الزيادة العربية والإندونيسية و تأديّتها في }
$$

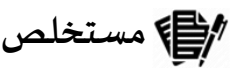

منذ 28 أكتوبر 1928 تكون اللغة الإندونيسية لغة رسمية في

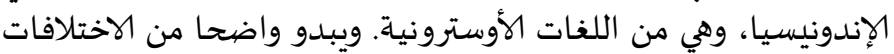

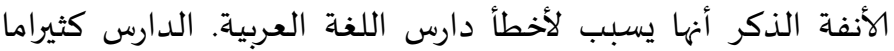

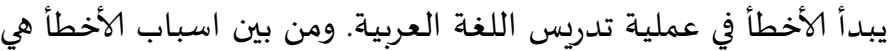

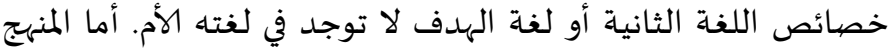
الذي انتجته الباحثة في هذه الدراسة فهو البحث البحثة الوصيفي والمنهج

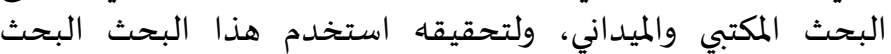

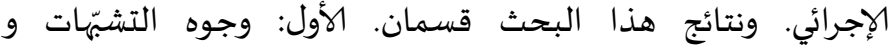

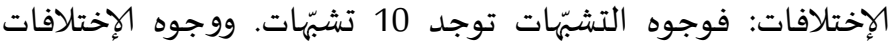

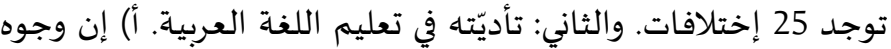

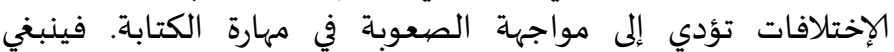

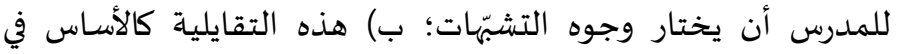

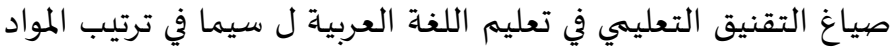

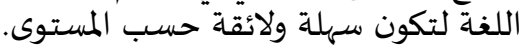

$$
\text { ج) نغيرات الزيادة العربية و الإندونيسية ، التقابل اللغوي }
$$

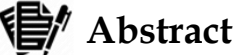

Since 28 October 1928, Indonesian has been an official language in Indonesia, an Austro-Hungarian language. It seems clear from the above differences that it causes the error of the student of the Arabic language. The student begins the error in the process of teaching Arabic. Among the reasons for the error are the characteristics of the second language or target language not found in his mother tongue. The method produced by the researcher in this study is the descriptive research and the method of research desk and field, and to achieve this research used the research procedure. The results of this research are two sections. The first: the faces of the simulations and differences: Fujo the similitude There are 10 similarities. The differences are 25 differences. The second is his performance in the teaching of the Arabic language. a) The differences between the differences in the skills of writing. The teacher should choose the faces of the simulations; b) This is the basis for the formulation of educational standards in the teaching of the Arabic language, especially in the arrangement of language materials to be easy and appropriate by level.

Education, Quality, Redirection, Reevaluation 


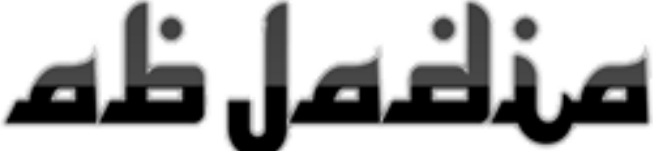
International Journal of Education



\section{霓" Abstrak}

Sejak 28 Oktober 1928, bahasa Indonesia resmi sebagai bahasa nasional. Bahasa Indonesia termasuk bahasa Austronesia, dan bahasa Arab termasuk rumpun bahasa Semit. Perbedaan rumpun ini menyebabkan Interferensi bahasa. Peneliti memakai analisis kontrastif dengan instrumen: dokumentasi, observasi dan wawancara. Hasil penelitian ini: 1) Persamaan dan perbedaan afiksasi dalam bahasa Arab dan Indonesia. Ada sepuluh persamaan dan dua puluh lima perbedaan meliputi faidah afiksasi dalam kedua bahasa. 2) Implikasi anakon terhadap kemampuan menulis: a) anakon bisa untuk meramal kesalahan siswa dalam belajar bahasa asing (bahasa kedua). Butir-butir perbedaan pada bahasa pertama dan kedua memberikan kesulitan kepada siswa. Sebaiknya guru mamakai butir-butir yang sama untuk mempermudah siswa mempelajari bahasa kedua; b) secara konsisten, anakon berkontribusi sebagai alat pengendali penyusunan materi pengajaran dari bahasa kedua secara efisien. Dengan membandingkan perbedaan pada setiap tataran analisis bahasa, bahan ajar dapat disusun sesuai dengan tingkat kesulitan masing-masing tataran

Afiksasi Bahasa Indonesia dan Bahasa Arab, Analisa Kontrastif

http://- $\quad$ http://ejournal.uin-malang.ac.id/index.php/abjadia/article/view/5310

مقدمة

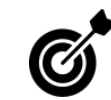

ذهب وينا سـانجايا (wina sanjaya)، كان في التدريس نظام التدريس، وهو توحيد العنصر لا ينفصل

بعضها بعضا في تحصيل الهدف الواحد، منها الإنسان والمادة الوصيلة والجهاز والإجراءات. ويتكوّن الإنسان هنا من التلميذ والمدرّس وكل من يساعد على نجاح التدريس (Sanjaya 2008). ومن المحقق أنّ التلميذ من أهمّ موضع في عملية التدريس (Ahmadi 2007) . ولغة الأم هي اللغة التى اكتسبها الطفل قبل يدرس اللغة الأخرى (Nababan 1983) ، وأمّا اللغة الثانية فهي اللغـة التي يدرسها الشخص بعد اكتساب لغة الأم (Arifuddin 2010). وفي الواقع أنّ عملية التدريس اللغة العربية هي من عملية تدريس اللغة الأجنبياة، لأنّ اللغة العربية ليست لغة الأم، لاسيّما عند إندونيسين.

اللغة العربية تمثّل اللغة لاتصال العربين في بلدهم. وهي لغة القران، ويتكلّم بها كل من في

الجزيرة العبية قبل مجيء الإسلام بألف سنة (Fahri 2007) . وهي من اللغات السـاميّة (Ma'nawi 1999). واللغة الإندونيسية تمثّل اللغة لاتصال الإندونيسين وتكون هذه اللغة منذ 28 أكتوبر 1928 ميلادي لغة رسميتا في الإندونيسيا، وهي من اللغات الأوسترونية (Marsono 2011) ويبدو واضحا من الاختلافات الأنفة الذكر أنها يسبب لأخطأ دارس اللغة العربية. الدارس كثيراما يبدأ الأخطأ في عملية تدريس اللغة العربية. ومن بين اسباب الأخطأ هي خصائص اللغة الثانية أو لغة الهدف لا توجد في لغته الأم. 
على حدّ تعبير أحمد خاطب و أصحابه أنّ مشكلة تعليم اللغة العربية بصفتاه اللغة الثانية لتلاميذ إندونيسيين تنقسم إلى القسمين مشكلة لغوية و غير لغوية (Chotib 1976) . وقد كان مشكلة تعليم اللغة العربية لغير ناطقين بها التي سبّبها خصائصها بحثا لباحثين في تعليم اللغة العربية وعند علي الحديدي، في محاضرة بالموضيوع "تعليم اللغة العربية" في مادريت في سنة 1959 قد اتّفق أنّ من مشكلات تعليم اللغة العربية اللغوية لغير ناقين بها الصوتية والمفردات وقواعد اللغة (Al-Hadidi n.d.). أما عناصر اللغة هي الصيوتيات و الصرف و المفردات (Muhammad 2013).

للكلمات العربية حالتان: حالة إفراده و حالة تركيب. فالبحث عنها، وهي مفرد، لتكون على وزن خاصّ وهيئة خاصية هو منموضوع علم الصرف (الغلابينى n.d.). فالصرف علم بأصهول تعرف بها صيغ الكلمات العربية وأحوالها التي ليست بإعراب ولا بناء وهو علم يبحث عن الكلم من حيث ما يعرض لله من تصريف وإعلال وإدغام وإبدال. وبه نعرف نعرف ما يجب أن تكون عليه بنية الكلمة قبل انتظام في الجملة. وهو من أهمّ العلوم العبية. ويتب على كل أديب وعلم أن يعرفه، خشية الوقوع في أخطأ يقع فيها كثير من المتأدبين (الغلابينى n.d.). وها هو المختلف بين اللغة العربية و الإندونسية الذي يسبب صعوبة في دراسة أي في الصرفية أو المورفولوجية. ومن أعمال المورفولوجية هي تغيرات الزيادة. وقد اختلف عملية تغيرات الزيادة في كلّ اللغات، بطريقة مماثل اختلفت في اللغة العربية واللغة الإندونسية. و علي ضوء هذا الإختلاف نستطيع أن نعرف أنه مشكلة في تعلّم اللغة العربية، عند مدرّس أم دارس على حدّ سواء. لأنّ الدارس قد اعتاد تكلّما بلغة ألأمّ فلذلك ستوجد الأخطأ عندما يعبّرها الدارس.

وقد يعبّر الدارس في اللغة العربية كما يعبّر في اللغة الإندونسية. ولا يستخدم قواعد اللغة العربية الأصح (أي: في تغيرات الزيادة) نحو: "أقام الخيام" يريد بها "ضرب الخيام"، والصحيح هو "خيّم". ولا ينبغي لنا أن نهمل هذه المشكلة، كيلا تكون عاقبة سيّئة في مهارة الكتابة. لأنّ الكتابة الجيّدة هي الكتابة الصحيحة في النحو و الصرف. هذه التصريحات تقرر بوضيوح أنّ مشكلة تأثير لغة الأم (في عملية تغيرات الزيادة) في تعلّم اللغة الثانية/هدف مشكلة خطيرة، فلا بدّلنا أن نحلّها. وفي هذه الحدود عرض الباحث الحلول وهو التحليل التقابلية.

الدراسة التقابلية هي تقابل بين لغة الأم واللغة الثانية اللتان لهما نظام مقياس وقواعد متّفَقة، يعني تقابل بين لغة الأم و لغة الهدف لمعرفة مساوتهما وتفريقهما (Parera 1997). وفي ضوء إدراك جوز دنيل فريرا (jos daniel parera) التحليل التقابلية لها منافع، منها بوسيلة هذه الدراسـة نستطيع أن 
نتنبّأ أخطأ الدارس في تعلّم اللغة الثانية وأن ننقص التداخل في تعلّم اللغة الثانية(Parera 1997). على هذه الملاحظة السابقة، يكون أنّ هذا البحث مهمّ. وبدون فهم و معرفة كيف تكون تغيرات الزيادة (afik) في لغة الهدف، تحدث أخطأ في تعلّمها كثيرا.

وكان دارس اللغة العربية في إندونسيا كثيرا ومع ذلك التداخل يستطيع أن يسبب الأخطأ في تعبير اللغة، ووعلى ضوء هذه الأدلّة بحث الباحث تقابل تغيرات الزيادة (afiksasi) اللغة العربية واللغة

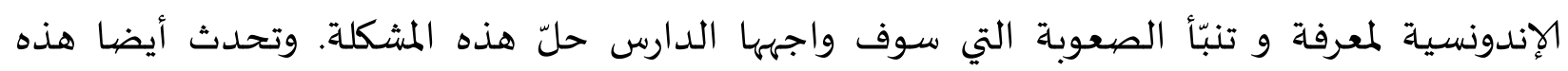
المشكلة في قسم تعليم اللغة العربية، كما قالت أحد المدرّسات فهيا، أنّ كثيرا من طلاب ليس لهم تمام القدرة في صناعة تغيرات الزيادة (afiksasi) اللغة العربية. وهذه الظاهرة التي تشجع الباحث أن يبحث بالتحليل التقابلي في هذا الفصل.

\section{[0]}

مدخل البحث هو المدخل الكيفي، وهو إجراء البحث الذي يحصل إلي جمع البيانات الوصية مثل

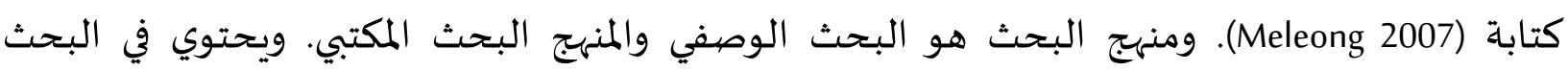

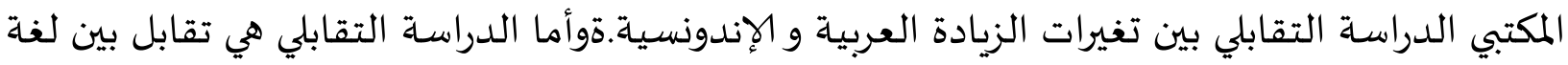

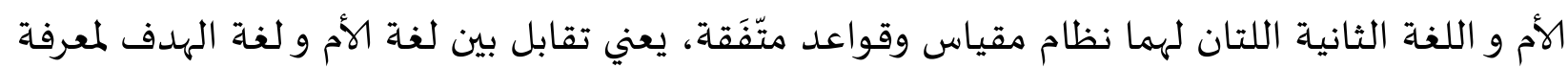
مساوتهما وتفريقهما (Parera 1997).

المصادر الرئيسية هي البيانات التي لها صلة بالمبحوث مباشرة (Prastowo 2011). والمصادر الرئيسية في

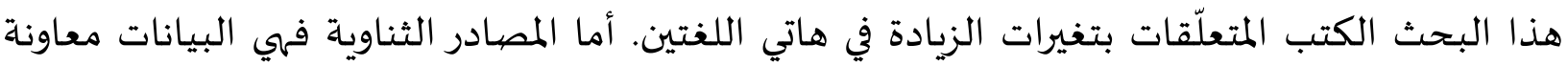

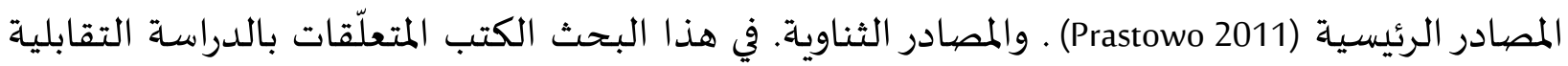
بين هاتي اللغتين.

وأما مجتمع البحث في هذا البحث فهو طلبة الفصل A مستوى رابعة قسم تعليم اللغة العربية

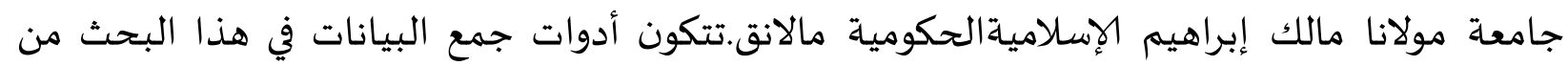

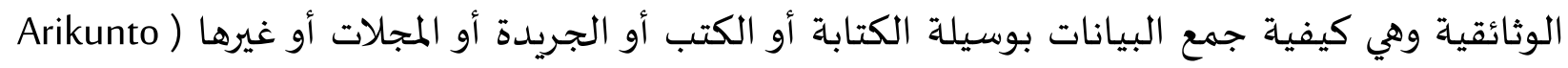

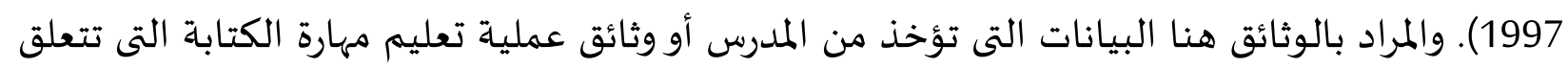

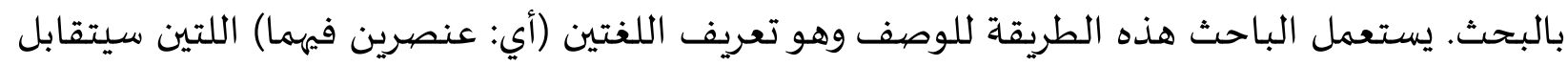

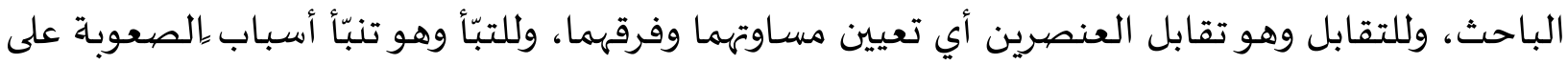

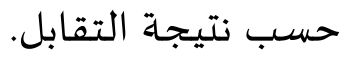


أمّا المنهج المستخدم لتحليل البيانات هو المنهج الوصفي (deskriptif) توصف المظاهر اللغويّة بغير محاولة إيجاد العلل والأسباب. أي أنه يقتصر على عرض الاستعمال اللغوي لدي مجموعة معينة، في زمان معين(شهلين 1980). ونعرف المنهج الوصفي أنّه أسلوب من أساليب التحليل المركّز على معلومات كافية ودقيقة عن ظاهرة أو موضوع محدّد، أو فترة من فترات زمنية معلومة، وذالك من أجل الحصول على معلى نتائج علمية، ثمّ تفسيرها بطريقة موضوعية،، بما ينسجم مع المعطيات الفعلية للظاهرة. وقد يقتصر هذا المنهج على وضع قائم في فترة زمنية محددة أوتطويرا يشمل عنده فترات زمنية. يعتبر الوصف ركنا أسـاسياً من أركان البحث العلمي، ومنهجهاه من أهمّ المناهج المتبعه فياه، إذ إنّ الباحث الذي يرغب في الوصول إلى نتائج علميّة يعتمد عليها لابدّ من أن يحرص على وصفي الوضع من الراهن للظاهرة، وذلك برصدها وفهم مضمونها والحصول على أوصاف دقيقة وتفصيلية لها بغية الإجابة

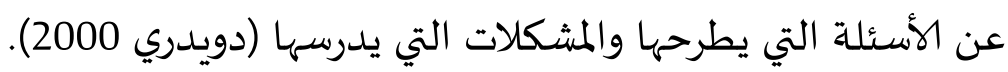

ونستخدم تحليل الدّراسة التقابلية على مذهب علم اللغة البنيوي الذي يتركّز في التركيب بين اللغة الأولى واللغة الثانية على وصفهما وتقابلهما في نفس المحتوى (Saville-Troike 2006). بدأت الدراسـة التقابليـة بوصف البيانات المختارة. ورأى جاميس أنّ هناك المرحلتين الأسـاسيّتين وهما الوصف والتقابل.

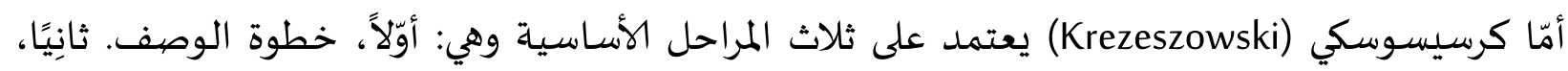


التقابلية التطبيقية على مجال تعليم اللغةة) و في مرحلة التنبؤ اختارى الباحث على نظريّة كلفرود (Clifford) التي تنقسم إلى ستة المراحل وهي

:(Brown 2007)

مرحلة الصفر (Transfer): لا فرق بين اللغة الأولى و اللغة الثانية؛

المرحلة الأولى (perpaduan): جزء من اللغة الأولى الذي يشكّل شكلا جديدا في اللغة الثانية؛

المرحلة الثانية (subdiferensiasi): جزء في اللغة الأولى غير موجود في اللغة الثانية؛

المرحلة الثالثة (reinterprestasi): جزء من اللغة الأولى الذي يشكّل شكلا جديدا في اللغة

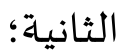

المرحلة الرابعة (overdiferensiasi): جزء من الغة الثانية الذي ما وجد في الغة الأولى؛ المرحلة الخامسـة (pembelahan): جزء واحد في اللغة الأولى ينقسم أو يتفرّع إلى فرعين أو عدّة 


\section{تغيرات الزبادة الإندونسية}

السبابق

يزاد -me في أول الكلمةة، و يدلّ على معنى(Dardjowidjojo 1988): (1) أصبح، نحو membatu. (2)

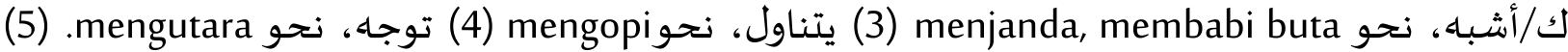

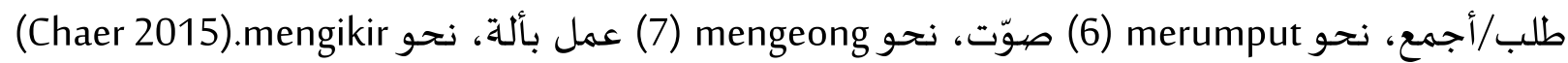

\begin{tabular}{|c|c|c|c|}
\hline معنى & 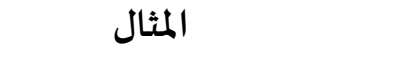 & 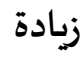 & الرقم - ال \\
\hline أصبح & membatu & \multirow{7}{*}{ me- } & 1 \\
\hline ك/أشبه & menjanda, membabi buta & & 2 \\
\hline 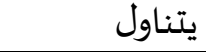 & Mengopi & & 3 \\
\hline ت توجاه & Mengutara & & 4 \\
\hline طلب/أجمع & Merumput & & 5 \\
\hline صيوّت & Mengeong & & 6 \\
\hline عمل بألة & Mengikir & & 7 \\
\hline
\end{tabular}

يزاد -ber في أول الكلمة،، لو كانت الكلمة الأصل من الإسهم فيدلّ على معنى (Alwi 2003)، مثل: (1)

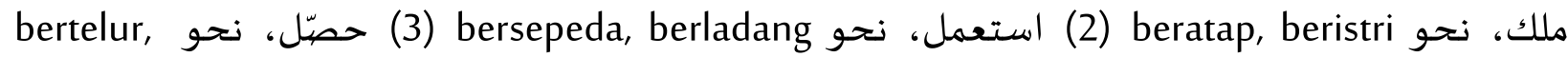
berkata. لو كانت الكلمة الأصل من العدد فيدلّ على: في مجموع، نحو berdua, berpuluh-puluh. ولو كانت الكلمة الأصل من الضمير فيدلّ على: استعمال الكلمة، نحو beraku

\begin{tabular}{|c|c|c|c|}
\hline معنى & المثال & الزيادة & 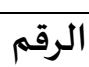 \\
\hline  & beratap, beristri & \multirow{5}{*}{ ber- } & 1 \\
\hline استعمل & bersepeda, berladang & & 2 \\
\hline حصيّل & bertelur, berkata & & 3 \\
\hline في مجموع & berdua, berpuluh-puluh & & 4 \\
\hline استعمل الكلمة & Beraku & & 5 \\
\hline
\end{tabular}

يزاد -di في أول الكلمة و من فائدتاه أن يجعل الفعل المفهوم مجهولا، مفردا كان أو جمعا

\begin{tabular}{|c|c|c|c|}
\hline فائدة & مثال & زيادة & رقم \\
\hline مجهول & Dipercayai & di- & 1 \\
\hline
\end{tabular}

يزاد -ter- في أول الكلمة و يدلّ على: (2003 Alwi): (1) مصيادفة أو غير عمد، نحو terbawa (2)

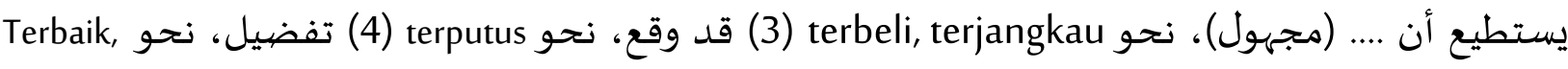
(Chaer 2015) tercantik يزاد -per في أول الكلمة، و يدلّ على معنى (2001 2amlan): (1) إجعل ....

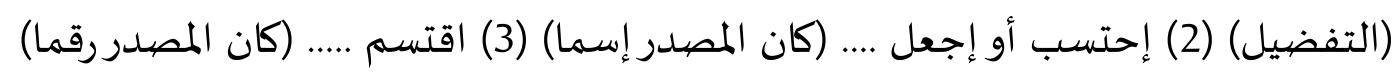

\begin{tabular}{|c|c|c|c|}
\hline معنى & 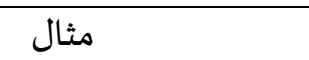 & زيادة & رقم \\
\hline إجعل .... (التفضيل) & Pertinggi, perlebar. & \multirow{3}{*}{ Per- } & 2 \\
\hline إحتسب أو إجعل .... (كان المصيدر إسما) & Perbudak, peristri & & \\
\hline اقتسم ..... (كان المصدرر رقما) & Perdua, perdelapan & & \\
\hline
\end{tabular}


يزاد -ber في أول الكلمة و an- في أخير الكلمة. يدلّ على: (1) التكثير (2) المشاركة (3) المشاركة في (4) عمل يعمل مرارا في أصل الكلمة

\begin{tabular}{|c|c|c|c|}
\hline معنى & 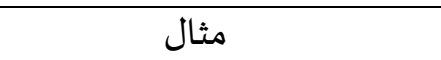 & الزيادة & 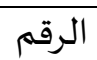 \\
\hline التكثير & Berlarian, bermunculan & \multirow[t]{4}{*}{ Ber-an } & \multirow[t]{4}{*}{1} \\
\hline المشاركة & Bermusuhan, bersentuhan & & \\
\hline المشـاركة في & Berhadapan, berseberangan & & \\
\hline عمل يعمل مرارا في أصل الكلمة & Berloncatan, bergulingan & & \\
\hline
\end{tabular}

يزاد -per في أول الكلمة و kan- في أخير الكلمة. و يدلّ على(Chaer 2015): (1) إجعل مادة .... (2)

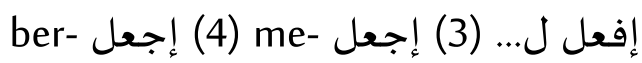

\begin{tabular}{|c|c|c|c|}
\hline معنى & المثال & الزيادة & الرقم \\
\hline إجعل مادة .... & Perdebatkan, pertanyakan & \multirow[t]{4}{*}{ Per-kan } & \multirow[t]{4}{*}{2} \\
\hline إفعل ل... & Persamakan, pertegaskan & & \\
\hline إجعل me- & Perdengarkan, perlihatkan & & \\
\hline إجعل -ber- & Pertemukan, pergunakan & & \\
\hline
\end{tabular}

يزاد -Per في أول الكلمة و i- في أخير الكلمة. ويلّ على: (1) إعمل ل..... (2) إعمل .... (أصل الكلماة)

\begin{tabular}{|c|c|c|c|}
\hline المعنى & المثال & الزيادة & الرقم \\
\hline إعمل ل...... - ل & Perbaiki, perbarui & \multirow[t]{2}{*}{ Per-i } & \multirow[t]{2}{*}{3} \\
\hline إعمل .... (أصل الكلمة) المفعول & Persetujui, pergauli & & \\
\hline
\end{tabular}

يزاد -ke في أول الكلمة و an في أول الكمة. و يدل على: (1) أصاب الشيئ (2) ذو صفة

\begin{tabular}{|r|r|r|c|}
\hline Kebanjiran, kebakaran & Ke-an & 4 \\
\hline Kekuningan, kebiruan & & \\
\hline
\end{tabular}

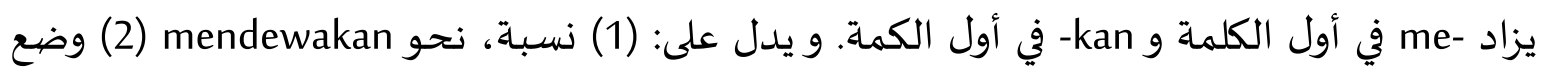

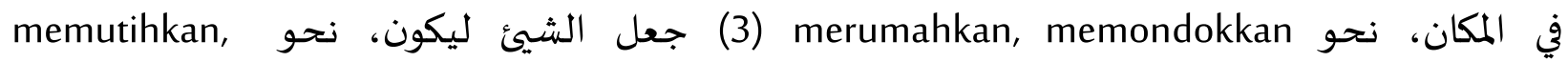



\begin{tabular}{|c|c|c|c|}
\hline معنى & المثال & الزيادة &  \\
\hline نسبة & mendewakan & \multirow[t]{4}{*}{ me-kan } & 1 \\
\hline وضع في المكان & merumahkan, memondokkan & & 2 \\
\hline جعل الشيئ ليكون & memutihkan, menghijaukan & & 3 \\
\hline يعمل لشخص آخر & membelikan, menjualkan & & 4 \\
\hline
\end{tabular}


menggulai, سيزاد -me في أول الكلمة و i- في أول الكماة. و يدل على: (1) أتمّ/وضع، نحو جembumbui

(4) memasuki, mendatangi

\begin{tabular}{|c|c|c|c|}
\hline & 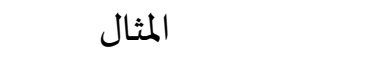 &  & 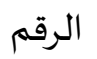 \\
\hline أتمّ/وضع & menggulai, membumbui & \multirow[t]{3}{*}{ Me-i } & 1 \\
\hline جعل المفعول كذا & memanasi, mengotori & & 2 \\
\hline يفعل الشيء في .... & memasuki, mendatangi & & 3 \\
\hline
\end{tabular}

تغيرات الزيادة العربية

أفعل : بزيادة همزة القطع في أوله للتعدية و لدخول في الزمان و المكان و سلب المعنى (إزالة معنى الفعل عن المفعول) و إستحقاق صفة معينة و التكثير و الوصول (بوخدود 1988) و قصد المكان و وجود ما اشتقّ منـه الفعل فى الفاعل و المبالغة و وجدان الشيئ في صفة و صيرورة و تعريض (معصوم n.d.) والدعاء (السليم 1428).

\begin{tabular}{|c|c|c|c|}
\hline 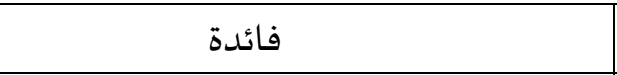 & مثال & 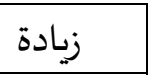 & رقم \\
\hline 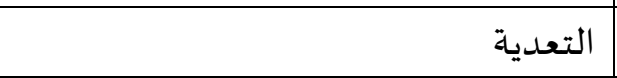 & أخرج & \multirow{12}{*}{ أ-....... } & \multirow[t]{12}{*}{1} \\
\hline الدخول في الزمان و المكان & أصبح & & \\
\hline سلب المعنى (إزالة معنى الفعل عن المفعول) & أشكيت زيدا & & \\
\hline إستحقاق صفة معينة & أحصد الزرع & & \\
\hline 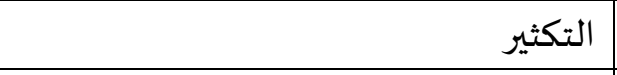 & أشجر المكان & & \\
\hline الوصول الى & 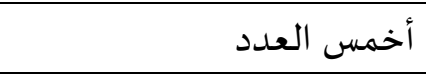 & & \\
\hline قصد المكان & أعرق & & \\
\hline وجود ما اشتقّ منـه الفعل في الفاعل & أثمر الطلع & & \\
\hline وجدان الشيئ في صفة & أعظمتاه & & \\
\hline 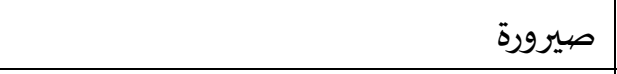 & 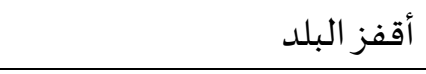 & & \\
\hline تعريض & 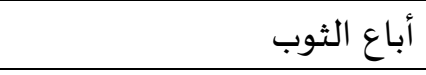 & & \\
\hline  & أسقيته: أي دعوت له بالسقيا & & \\
\hline
\end{tabular}

إنفعل : بزيادة ألف و نون. وزن إنفعل لا يكون إلا لازما. فإذا كان الفعل المجرد الثلاثي متعديا

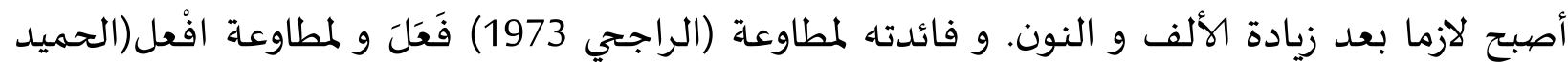

\begin{tabular}{|c|c|c|c|}
\hline فائدة & مثال & زيادة & رقم \\
\hline للمطاوعة & إنفتح & إنف-........ & 2 \\
\hline
\end{tabular}


إستفعل : بزيادة الألف و السين و التاء للطلب والتحول وإعتقاد الصفة وإختصيار الكلمة (السليم 1428) والوجدان على صفة و التكلف و معنى فعل المجرد و المطاوعة.

\begin{tabular}{|c|c|c|c|}
\hline 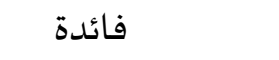 & مثال & 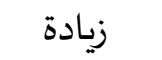 &  \\
\hline 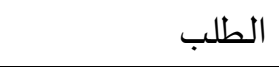 & إستغفر & \multirow[t]{8}{*}{ إست- ....... } & \multirow[t]{8}{*}{3} \\
\hline التحول التحول & إستحجر الطين (صار حجرا) & & \\
\hline إعتقاد الصفة & إستكرمته (إعتقدته كريما) & & \\
\hline إختصار الكلمة & إسترجع (فال : إنا لله و إنا إليه راجعون & & \\
\hline الوجدان على صفة & استعظمت & & \\
\hline التكلف & استجرأ & & \\
\hline معنى فعل المجرد & 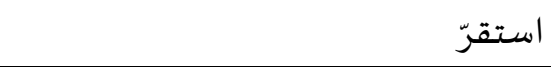 & & \\
\hline المطاوعة & أراحه، فاستراح & & \\
\hline
\end{tabular}

أفعل : بزيادة همزة القطع في أوله للتعدية و لدخول في الزمان و المكان و سلب المعنى (إزالة معنى الفعل عن المفعول) و إستحقاق صفة معينة و التكثير و الوصول و قصد المكان و وجود ما اشتقّ مناه الفعل في الفاعل و المبالغة و وجدان الشيئ في صفة و صيرورة و تعريض و الدعاء.

\begin{tabular}{|c|c|c|c|}
\hline 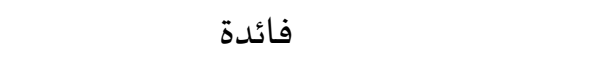 & 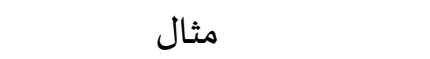 & 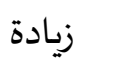 & 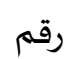 \\
\hline التعدية & أخرج & \multirow[t]{12}{*}{ أ- ....... } & \multirow[t]{12}{*}{1} \\
\hline الدخول في الزمان و المكان & أصبح & & \\
\hline سلب المعنى (إزالة معنى الفعل عن المفعول) & أشكيت زيدا & & \\
\hline إستحقاق صفة معينة & أحصد الزرع & & \\
\hline التكثير & أشجر المكان & & \\
\hline الوصول الى & أخمس العدد & & \\
\hline قصد المكان & أعرق & & \\
\hline وجود ما اشتقّ منه الفعل في الفاعل & أثمر الطلع & & \\
\hline وجدان الشيئ في صفة & أعظمتـه & & \\
\hline صيرورة & أقفز البلد & & \\
\hline تعريض & أباع الثوب & & \\
\hline 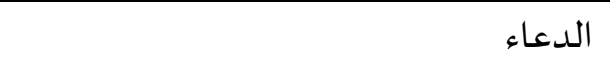 & أستيته: أي دعوت له بالسقيا & & \\
\hline
\end{tabular}

إنفعل : بزيادة ألف و نون. وزن إنفعل لا يكون إلا لازما. فإذا كان الفعل المجرد الثلاثي متعديا

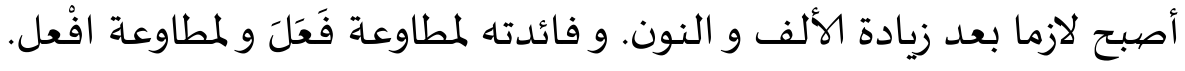

\begin{tabular}{|c|c|c|c|}
\hline فائدة & مثال & زيادة & رقم \\
\hline للمطاوعة & إنفتح & إنف-....... & 2 \\
\hline
\end{tabular}


إستفعل : بزيادة الألف و السين و التاء للطلب و التحول و إعتقاد الصفة و إختصار الكلمة و الوجدان على صفة و التكلف و معنى فعل المجرد و المطاوعة.

\begin{tabular}{|c|c|c|c|}
\hline فائدة & مثال & ز إدة & رقم \\
\hline 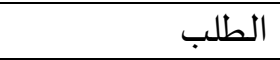 & إستخفر & \multirow[t]{8}{*}{ إست- ...... } & \multirow[t]{8}{*}{3} \\
\hline 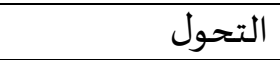 & إستحجر الطين (صار حجرا) & & \\
\hline إعتقاد الصففة & إستكرمته (إعتقدته كريما) & & \\
\hline إختصهار الكلمة & إسترجع (فال : إنا لله و إنا إليه راجعون & & \\
\hline الوجدان على صفة & استعظمت & & \\
\hline التكلف & استجراً & & \\
\hline معنى فعل المجرد & استقرّ & & \\
\hline المطاوعة الما & أراحه، فاستراح & & \\
\hline
\end{tabular}

إفتعل : بزيادة الألف و التاء للمطاوعة والمشاركة والمبالغة والمبالغة و الإتخاذ التصرف والاجتهاد

والاختيار

\begin{tabular}{|c|c|c|c|}
\hline فائدة & مثال & زيادة & رقم \\
\hline المطاوعة & جمعتهم فاجتمعوا & \multirow{6}{*}{ إ-ت............. } & \multirow[t]{6}{*}{1} \\
\hline المشاركة & إختلف أحمد و على & & \\
\hline المبالغة & إكتسب علما كثيرا & & \\
\hline الإتخاذ & إكتال (إتخذ كيلا) & & \\
\hline التصرف و الاجتهاد & اكتسب & & \\
\hline الاختيار & انتقى، اصطفى & & \\
\hline
\end{tabular}

تفعّل : بزيادة التاء و تضعيف العين ليطاوع وزن فعّل و التكلف و الإتخاذ و التجنب و الطلب.

\begin{tabular}{|c|c|c|c|}
\hline فائدة & مثال & زيادة & رقم \\
\hline يطاوع وزن فعّل & علّمتحته فتعلّم & \multirow{5}{*}{ ت- و تضعيف العين } & \multirow[t]{5}{*}{2} \\
\hline التكلف & تصبّر ، تشجّع & & \\
\hline الإتخاذ & تسنّم أحمد المجد & & \\
\hline التجنب & تجهّد (ترك الجهود) & & \\
\hline الطلب & تعظّم، تيقّن & & \\
\hline
\end{tabular}

إفعلّ : زيادة الألف و تضعيف الام و وزن إفعلّ لا يكون إلا لازما، و يأتي من الأفعال الدالة على الألوان والعيوب بقصيد المبالغة فيها

\begin{tabular}{|c|c|c|c|}
\hline فائدة & مثال & زيادة & رقم \\
\hline 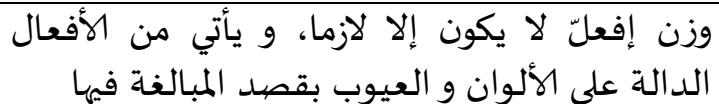 & إصفرّ الورق & إ-......... و تضعيف الام & 3 \\
\hline
\end{tabular}

إفعوعل : بزيادة الألف والواو و تكرير العين للمبالغة و قوة

\begin{tabular}{|c|c|c|c|}
\hline فائدة & مثال & زيادة & رقم \\
\hline للمبالغة و قوة & | إعشوشب & الألف والواوو تكرير العين & 4 \\
\hline
\end{tabular}




$$
\text { إفعالٌ : بزيادة ألف الوصل، ثم ألف و تكرير اللام للمبالغة }
$$

\begin{tabular}{|c|c|c|c|}
\hline فائدة & 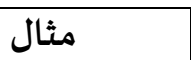 & زيادة & 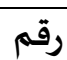 \\
\hline 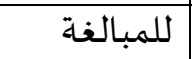 & 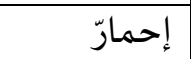 & ألف الوصل، ثم ألف و تكرير اللام & 5 \\
\hline
\end{tabular}

إفعوّل : بزيادة الألف و واو مضعفة للمبالغة

\begin{tabular}{|c|c|c|c|}
\hline فائدة & مثال & زيادة & رقم \\
\hline للمبالغة & إجلوّذ & بزيادة الألف و واو مضعفة & 6 \\
\hline
\end{tabular}

تفاعل : بزيادة التاء و الألف للمشاركة، لاظهار ما ليس في الواقع، للوقوع تدريجا ، لمطاوعاة فاعل.

\begin{tabular}{|c|c|c|c|}
\hline الفائدة & المثال & الزيادة & الرقم \\
\hline مشاركة & تضارب & \multirow[t]{4}{*}{ ت..1 } & 1 \\
\hline اظهار ما ليس في الواقع & تمارض & & 2 \\
\hline وقوع تدريجا & توارد & & 3 \\
\hline مطاوعة فاعل & باعدت - فتباعد & & 4 \\
\hline
\end{tabular}

فعّل : بتضعيف العين، للتعدية والتكثير والمبالغة والتوجه والتشبياء والنسبة والسلب والإختصار ولاتخاذ الفعل من الاسمالدعاء،

\begin{tabular}{|c|c|c|c|}
\hline فائدة & مثال & زيادة & رقم \\
\hline التعدية & فرّح، خرّج & \multirow[t]{9}{*}{ تضيعيف العين } & \multirow[t]{9}{*}{1} \\
\hline التكثير و المبالغة & قتّل، عذّب & & \\
\hline التوجها & غرّب، شرّق & & \\
\hline التشبيا & حجّر الطين & & \\
\hline النسبة & كفّرت زيدا & & \\
\hline السلب & قشّّرت الفاكهة & & \\
\hline الإختصيار & كبّر، هلّل، سبّح & & \\
\hline اتخاذ الفعل من الاسم & خيّم & & \\
\hline 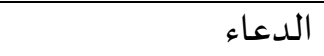 & سقيّيته أي قلت سقاك الله & & \\
\hline
\end{tabular}

فاعل : بزيادة ألف بين الفاء و العين للمشاركة و المتابعة و إضفاء صفة و التعدية و موالاة.

\begin{tabular}{|c|c|c|c|}
\hline فائدة & مثال & زيادة & رقم - ل \\
\hline المشاركة & ضـارب زيد عمرا & \multirow[t]{4}{*}{.......-I- } & \multirow[t]{4}{*}{2} \\
\hline المتابعة & واليت الصوم & & \\
\hline إضفاء صفة & عافاه الله (جعله ذا عافية) & & \\
\hline الموالة & تابعت القراءة & & \\
\hline
\end{tabular}

التقابل

من ذاك الوصف، وجد الباحث عدّة الاختلاف والتشبّهات بين تغيرات الزيادة في اللغة الإندونسية وتغيرات الزيادة في اللغة العبية كما في الجدول الآتي: 


\begin{tabular}{|c|c|c|c|c|c|}
\hline البيان & 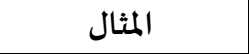 & اللغة 2 & 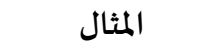 & اللغة 1 & الرقم \\
\hline يدل على التعدية & أخرج & من فائدة أفعل و عّل & $\begin{array}{l}\text { memanasi, } \\
\text { mengotori }\end{array}$ &  & 1 \\
\hline التشبياه & حجّر & من فائدة فعّل التشبياه & $\begin{array}{l}\text { menjanda, } \\
\text { membabi buta }\end{array}$ & عن فائدة -me يدل كن أشباء & 2 \\
\hline التكثير & أشجر المكان، قتّل & من فائدة أفعل وفعّل & $\begin{array}{l}\text { Berlarian, } \\
\text { bermunculan }\end{array}$ & Ber-an من فائدة & 3 \\
\hline قصد المكان & أعرق & من فائدة أفعل قصيد المكان & Mengutara & 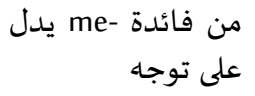 & 4 \\
\hline التوجها & غرّب & من فائدة فعّل التوجها & & & \\
\hline الفعل في الفاعل ماشتق منـاه & أثمر & من فائدة أفعل & $\begin{array}{l}\text { bertelur, } \\
\text { berkata }\end{array}$ & مصنّ فائدة & 5 \\
\hline \multirow[t]{3}{*}{ ذو صفة } & أستعظمته، & وجد فائدة أفعل واستفعل & \multirow[t]{3}{*}{$\begin{array}{l}\text { Kekuningan, } \\
\text { kebiruan }\end{array}$} & \multirow[t]{3}{*}{ صن فائدة Ke-an ذو } & \multirow[t]{3}{*}{6} \\
\hline & أحصد & صن من فائدة أفعل إستحقاق & & & \\
\hline & إستكرمته & من فائدة استفعل إعتقاد & & & \\
\hline صيرورة & أقفز & من فائدة أفعل صيرورة & \multirow[t]{2}{*}{ Membatu } & \multirow{2}{*}{ 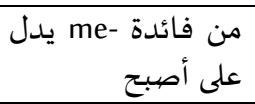 } & \multirow[t]{2}{*}{7} \\
\hline التحول & إستحجر & من فائدة استفعل التحول & & & \\
\hline 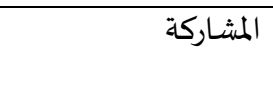 & تضيارب، ضهارب، & وفاعل وتائدة وزن افتعل & $\begin{array}{l}\text { Bermusuhan, } \\
\text { bersentuhan }\end{array}$ & Ber-an من فائدة & 8 \\
\hline النسبة & كفّر & من فائدة فحّل النسبة & mendewakan & النسبة فائدة me-kan & 9 \\
\hline التخاذ الفعل من & خيّم & من من فائدة فعّل اتخاذ الفعل & $\begin{array}{l}\text { bersepeda, } \\
\text { berladang }\end{array}$ & ber من فائدة & 10 \\
\hline
\end{tabular}

\begin{tabular}{|c|c|c|c|c|c|}
\hline البيان & المثال & اللغة 2 & المثال & اللغة 1 & 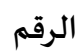 \\
\hline في الدلالة & فعّل، يفعّل & يدلّ على معنى في نفسهان & & - & 1 \\
\hline تعلق بالفاعل & فاعلت،تفاعلنا & يقبل ضيمير الفاعل & & - & 2 \\
\hline الفعل عن على إزالة معنى & أشفى، قشّر، & من فائدة وزن أفعل، فعِّل & & - & 3 \\
\hline يدلّ على تعربض & أباع & من فائدة وزن أفعل & & - & 4 \\
\hline يدلّ على الدعاء & أسقيته، سقّيتها & من فائدة وزن أفعل وفعّل & & - & 5 \\
\hline يدلّ على الطلب & تيقّن & متن فائدة وزن استفعل & & - & 7 \\
\hline والدجلّ على التصرف & اكتسب & من فائدة وزن إفتعل & & - & 8 \\
\hline يدلّ على الاختيار & انتقى، اصطفى & من فائدة وزن إفتعل & & - & 9 \\
\hline يدل على إختصار & إسترجع، كبّر & وفعَّ فائدة وزن استفعل & & - & 8 \\
\hline يدل على التجنب & تجهيّد & من فائدة وزن تفعّل & & - & 9 \\
\hline يدل الزمان على المكان الدخول في & أصبح & من فائدة وزن أفعل & & - & 10 \\
\hline يدل على الوصول الى & أخمس & من فائدة وزن أفعل & & - & 11 \\
\hline يدل على مطاوعة & إنفتح & من فائدة وزن و وإنفعل وتفعل & & - & 12 \\
\hline
\end{tabular}




\begin{tabular}{|c|c|c|c|c|c|}
\hline يدل على التكلف & استجراً & من فائدة وزن إستفعل & & - & 13 \\
\hline يدل على الإتخاذ & إكتال، تسنّم & من فئل فائدة وزن إفتعل & & - & 14 \\
\hline يدل على إضفاء صفة & عافاه الله & وزن فائدة وزن من فائدة & & - & 15 \\
\hline يدل على المبالغة & 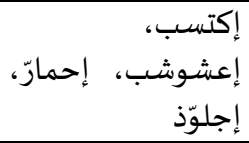 & من فإفعوعل وإفعال وإفعوّل & & - & 16 \\
\hline يدل على ملك & & - & beratap, beristri & ber- من فائدة & 17 \\
\hline يدل على تناول & & - & mengopi & me- من فائدة & 18 \\
\hline يدل على الإجماع & & - & merumput & me- من فائدة & 19 \\
\hline يدل على تصيويت & & - & mengeong & me- من فائدة & 20 \\
\hline يدل على عمل بألة & & - & mengikir & me- من فائدة & 21 \\
\hline يدل على في مجموع & & - & $\begin{array}{r}\text { berdua, berpuluh- } \\
\text { puluh }\end{array}$ & ber- من فائدة & 22 \\
\hline الكلمة على استعمال & & - & Beraku & ber- من فائدة & 23 \\
\hline يدل على مبني مجهول & & - & dipercayai & من فائدة-di & 24 \\
\hline يدل على وضيع في & & - & $\begin{array}{r}\text { merumahkan, } \\
\text { memosndokkan }\end{array}$ & من فائدة-me من & 25 \\
\hline
\end{tabular}

بعدما عمل الباحث بالتقابل بين تغيرات الزيادة العربية و الإندونسية، أقام الباحث التحليل عن التشبهات و الاختلافات فيهما باستخدام نظرية clifford التي قسّم صعوبات تعليم اللغة الأجنبية إلى ستّة مراحل. و اختصر الباحث عن تصنيف مراحل التنبّؤ فيما يلي:

\begin{tabular}{|c|c|c|c|c|}
\hline مرحلة التنبّؤ & البيان & اللغة 20 الم 2 & اللغة 1 & 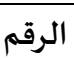 \\
\hline مرحلة الصفر (transfer 0) & يلت التعدية على & من فائدة أفعل و فعَل & 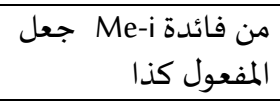 & 1 \\
\hline مرحلة الصفر(transfer 0) & يلت التشبيه على & من فائدة فعِّل التشبياه & من كلى فائدة -me يدل & 2 \\
\hline مرحلة الصفر(transfer 0) & يلتيثل على & من فائدة أفعل و فحّل التكثير & Ber-an من من مائدة & 3 \\
\hline المرحلة الخامسة(pembelahan) & يدل على توجه & من فائدة فعّل التوجهاه المكان & من فائدة -me يدل & 4 \\
\hline مرحلة الصفر(transfer 0) & تحصيل على & منه الفعل في الفاعل وجود ما اشتقّ & من فائدة -me حصيّل & 5 \\
\hline \multirow[t]{3}{*}{ المرحلة الخامسـ(pembelahan) } & \multirow[t]{3}{*}{ صيدل على ذي } & من فائدة أفعل و و استفعل & \multirow[t]{3}{*}{ من فائدة Ke-an ذو } & \multirow[t]{3}{*}{6} \\
\hline & & معينة فائدة أفعل إستحقاق صفة & & \\
\hline & & من فائدة استفعل إعتقاد & & \\
\hline المرحلة الخامسة(pembelahan) & يدل على أصبح & من فائدة أفعل صيرورة & 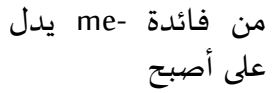 & 7 \\
\hline مرحلة الصفر(transfer 0) & يل المشاركة على & تفاعل المشائدةركة افتعل و فاعل و & Ber-an من & 8 \\
\hline
\end{tabular}




\begin{tabular}{|c|c|c|c|c|}
\hline مرحلة الصفر(transfer 0) & النسبة على & من فائدة فعَّل النسبة & $\begin{array}{ll}\text { me-kan من فائدة } \\
\end{array}$ & 9 \\
\hline مرحلة الصفر(transfer 0) & $\begin{aligned} \text { الفعل على اتخاذ } \\
\text { الفسم }\end{aligned}$ & من فائدة فعّل اتخاذ الفعل من & ber $\quad$ من & 10 \\
\hline المرحلة الرابعة(overdiferensiasi) & يدل على وقت & بزمان على معنى في نفسه مقترن & & 11 \\
\hline المرحلة الرابعة(overdiferensiasi) & متعلق بالفاعل & يقبل ضمير الفاعل & - & 12 \\
\hline المرحلة الرابعة(overdiferensiasi) & 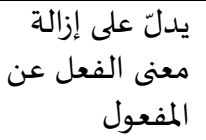 & 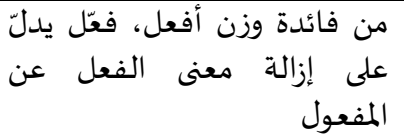 & - & 13 \\
\hline المرحلة الرابعة(overdiferensiasi) & تعرلّ على & تعريض فائدة وزن أفعل يدلّ على & - & 14 \\
\hline المرحلة الرابعة(overdiferensiasi) & يدلّ على الدعاء & ملى فائدة وزن أفعل و فعَّل يدلّ & - & 15 \\
\hline المرحلة الرابعة(overdiferensiasi) & 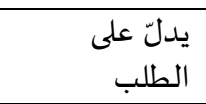 & يدلَ على الطلب وزن استفعل و تفعّل & - & 16 \\
\hline المرحلة الرابعة(overdiferensiasi) & التصلّ على و & 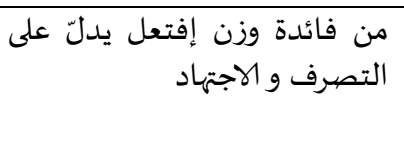 & - & 17 \\
\hline المرحلة الرابعة(overdiferensiasi) & يدلَّ على & من فائدة وزن إفتعل يدلّ على & - & 18 \\
\hline المرحلة الرابعة(overdiferensiasi) & إختصار الكلمة & يدل على إختصار الكلمة وزلمل و فعّل & - & 19 \\
\hline المرحلة الرابعة(overdiferensiasi) & يدل التجنب & من فائدة وزن تفعّل يدل على & - & 20 \\
\hline المرحلة الرابعة(overdiferensiasi) & 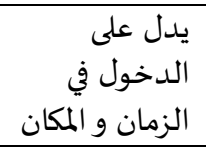 & من فائدة وزن أفعل يدل الدمان على المكان & - & 21 \\
\hline المرحلة الرابعة(overdiferensiasi) & الوصول على الى & من فائدة وزن أفعل يدل على & & 22 \\
\hline المرحلة الرابعة(overdiferensiasi) & مطاوعة على & 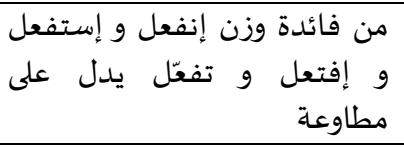 & - & 23 \\
\hline المرحلة الرابعة(overdiferensiasi) & يدلئل على & من فائدة وزن إستفعل يدل على & - & 24 \\
\hline المرحلة الرابعة(overdiferensiasi) & 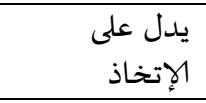 & من فلى ائدة وزن إفتعل و تفعّل & - & 25 \\
\hline المرحلة الرابعة(overdiferensiasi) & يدل على إضفاء & فاعل يدل على إضفاء صنائدة وزة وزن & - & 26 \\
\hline المرحلة الرابعة(overdiferensiasi) & المبالغة على &  & & 27 \\
\hline المرحلة الثانية(subdiferensiasi) & يدل على ملك & - & 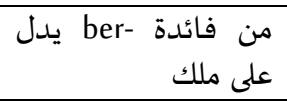 & 28 \\
\hline المرحلة الثانية(subdiferensiasi) & يدل على تناول & - & عن من فائدة -me يدل & 29 \\
\hline المرحلة الثانية(subdiferensiasi) & يدال يدل على & - & 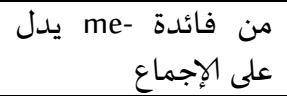 & 30 \\
\hline المرحلة الثانية(subdiferensiasi) & تصليت & - & على فائدة -me يدل & 31 \\
\hline
\end{tabular}




\begin{tabular}{|c|c|c|c|c|}
\hline المرحلة الثانية(subdiferensiasi) & بألة على عمل & - &  & 32 \\
\hline المرحلة الثانية(subdiferensiasi) & مجدل على في & - & 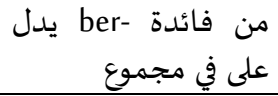 & 33 \\
\hline المرحلة الثانية(subdiferensiasi) & الدلدل على الكمال & - & من فائدة -ber يدل استعمال الكلمة & 34 \\
\hline المرحلة الثانية(subdiferensiasi ) & يدل على على مبني & - & من فبني مجهول في من يدل على & 35 \\
\hline المرحلة الثانية(subdiferensiasi ) & في المكان على وضع & & 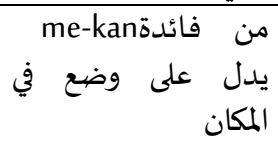 & 36 \\
\hline
\end{tabular}

كما لاحظنا في الجدول أن وجدنا 10 تشبّهات و 26 اختلافا بين هاتين اللغتين عند نظرية clifford ووضعت الباحثة مجموع المراحل المفصيّل كما يلي:

\begin{tabular}{|c|c|c|}
\hline الاختلافات & التشبهّهات & 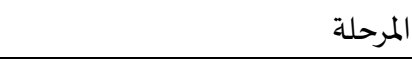 \\
\hline & 8 & مرحلة الصفر (transfer 0) \\
\hline & & المرحلة الأولى (perpaduan) \\
\hline \multirow[t]{2}{*}{9} & & المرحلة الثانية (subdiferensiasi) \\
\hline & & المرحلة الثالثة (reinterpretasi) \\
\hline \multirow[t]{2}{*}{17} & & المرحلة الرابعة (overdiferensiasi) \\
\hline & 2 & المرحلة الخامسة (pembelahan) \\
\hline
\end{tabular}

من هذا الجدول وجدنا أن أكثر التشبهات في تغيرات الزيادة بين هاتين اللغتين وقعت في المرحلة الصفر دليل على أن لا فرق بين اللغة الإندونيسية واللغة العربية. أمّا الباقي يدلّ على اختلاف بعيد بأن أكثر من 16 جزءاوقعت في المرحلة الثانية إلى أعلاها. اعتمادا على نظرية Clifford أن إذا كان الجزء من اللغة وقع في مرحل الصفر فيسهل على الطلاّب

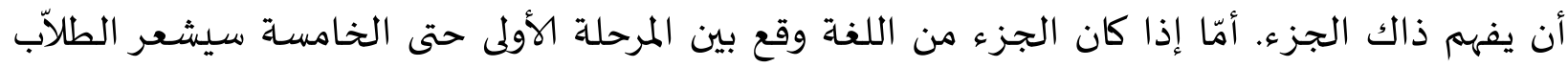
الصعوبة عند فهموه لأنّ فيه اختلاف ظاهر واضح بعيد عن ذهن الطلآب ويحتاج إلى شرح واهتمام أكثر في توضيحها. وبعدما عمل الباحث بالتنبؤ بين تغيرات الزيادة العربية و الإندونسية، أقام الباحث التوضيح بالمقابلة مع خبير في مادة مهارة الكتابة و الملاحظة في فصل A المستوى الرابعة. كما تقدّم أن أكثر التشبهات في تغيرات الزيادة بين هاتين اللغتين وقعت في المرحلة الصفر دليل على

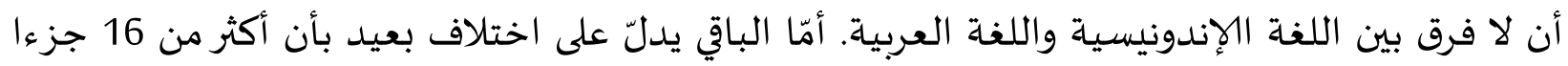
وقعت في المرحلة الثانية إلى أعلاها. اعتمادا على نظرية Clifford أن إذا كان الجزء من اللغة وقع في مرحل الصيفر فيسهل على الطلاّب

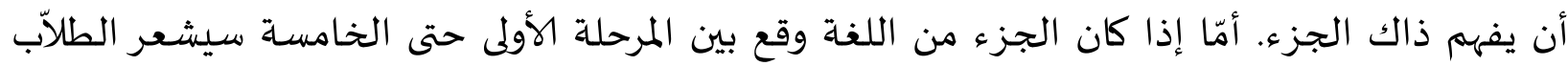


الصعوبة عند فهموه لأنّ فيه اختلاف ظاهر واضح بعيد عن ذهن الطلاّب ويحتاج إلى شرح واهتمام أكثر في توضيحها.

وعندما عمل بالتوضيح، وجد الباحث بعض نتيجة غير وفق للتنبؤ في الواقع. كاما في مرحلة

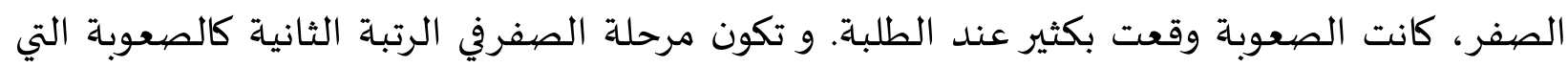
وقعت عند الطلبة كثيرا.

وكانت أكثر الصعوبة في المرحلة الرابعة ووجدت في الواقع بكثير، و العنصر موجود في اللغة الثانية لا في اللغة الأولى يسبّب هذه الصعوبة. لذالك عرفنا أن عند التداخل تأثير قويّ في تعليم اللغة الثانية. والصعوبة التي وقعت بقليل في المرحلة الثانية فالمرحلة الخامسة. و من أحد أسباب سهولة فههما

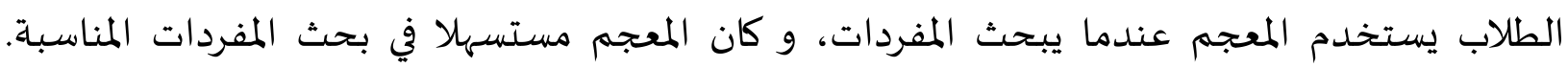

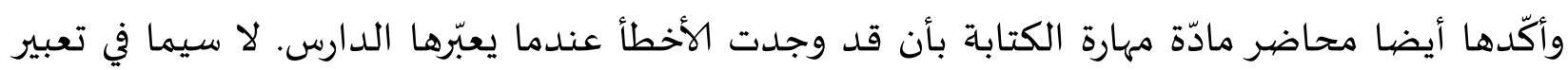

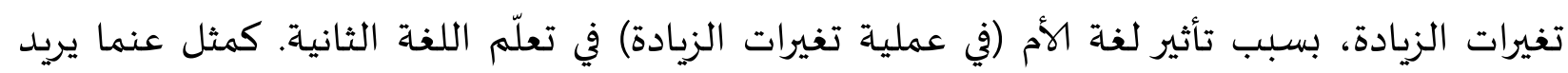

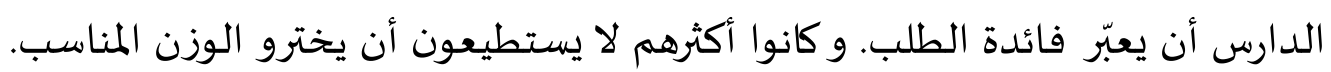
و هذه الأخطاء أو الصعوبة سبّبتها كفاءتهم الأساسية غير جيدة و أما الطلاب الذي لا يشعر هذه

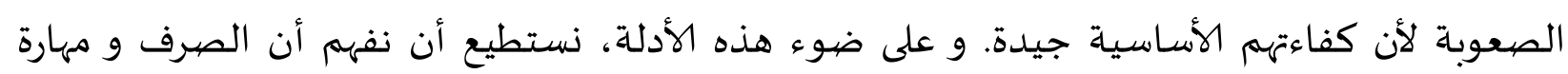

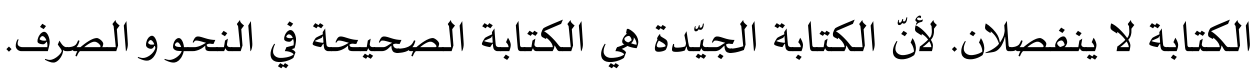
ولحل ذات الصعوبة، أولا، يجب على المدرّس أن يفهم تغيرات الزيادة في هاتين اللغة، و يبيّن

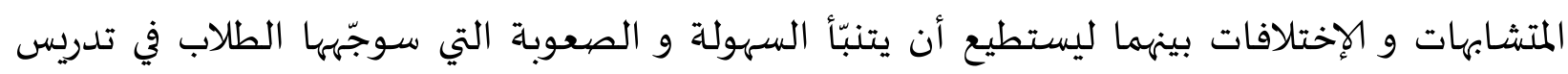



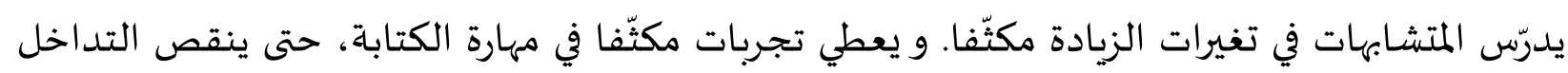
في تدريس تغيرات الزيادة.

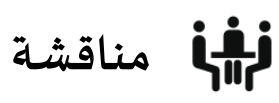

المتشابهات و الاختلافات

إجابة لسؤال البحث الأول وهي لمعرفة المتشاهات و الإختلافات بين تغيرات الزيادة العربية والإندونيسية فبحث الباحث و كتبها في الباب الرابع. 
كما قدّم في الباب الثالث، لإجابة سؤال البحث الأول استخدم الباحث أدوات جمع البيانات

Parera ( الوثائقية هي كيفية جمع البيانات بوسيلة الكتابة أو الكتب أو الجريدة أو المجلات أو غيرها 1997). و أما في هذا البحث جمع البيانات بوسيلة الكتب التي تكون المصادر الرئيسية في هذا البحث. وفي اختيار المصادر اختارى الباحث الكتب العلمياة، كما في اختيار الكتب الإندونيسية اختارى

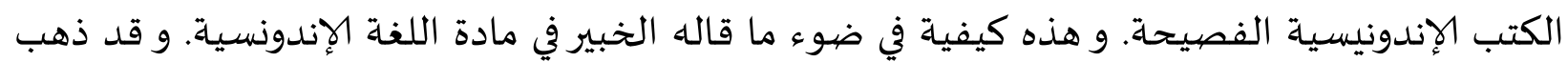
الخبير، بأن تكون في اللغة الإندونيسية لغة فصيحة، و هي اللغة التي لا أحد يستطيع أن يعيّها إلا من من فئه يختره الدولة أي رئيس دولة الإندونيسيا. وهو الطائفة التي أُسّست لاصنست فئناع نظام اللغة الإندونيسية الفصيحة.

كما سبق ذكرها في الباب الأول و الثاني و الثالث، لإجابة سؤال البحث الأول استخدم الباحث خطوتان، و هما الوصف و التقابل. و في الوصف يصف الباحث عن اللغات المتاقبلة، يعني جمع الباحث

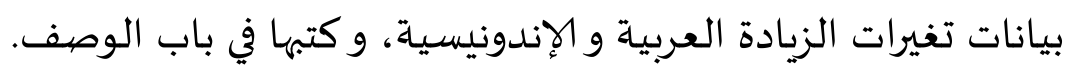

بعدما وصف تغيرات الزيادة فيقوم بالتقابل الباحث لمعرفة المتشابهات و الإختلافات في اللغة العربية و الإندونيسية. كيفيته، كتب الباحث المتشابهات و الإختلافات فيضعها في جدول المتشابهات وجدول الإختلافات، لذالك يُوجد جدولان في باب التقابل. و يقام هذه الكيفية ليسهّل التحليل ويسهّل من يقرأه في الفهم.

من الجدول التقابلي وجدنا 10 التشبهات و 25 الإختلافات في تغيرات الزيادة بين هاتين اللغتين من نحية الفائدة. و وجود التشبهات مناسب بنظرية اللغة الإجمالية (teori kesemestaan) التى قالت بأن كلّ اللغات لها التشبهات، على الأقل التشبهات في نظريتها (Tarigan 1992)

إجابة لسؤال البحث الثاني، استخدم الباحث أدوات جمع البيانات الوثائقية و المقابلة و الملاحظة. و خيّر الباحث الملاحظة في فصل A قسم تعليم اللغة العربية في المستوى الرابعة.

هنالك خطوتان لإجابة لسؤال البحث الثاني، و هما التبؤ و التوضيح. و التبؤ هي تنبّؤ عوامل الأخطاء والصعوبات في تعليم اللغة الأجنبية. و في هذه خطوة اختارى الباحث على نظريّة كلفرود التي تنقسم إلى ستة المراحل كما في الباب الثالث. (Clifford)

ووجدت أربعة المراحل في هذه خطوة، هناك 8 جزءا وقعت في مرحلة الصفر، فسوف يسهل على الطلاّب أن يفهم ذاك الجزء. و هناك 9 جزءا وقعت في المرحلة الثانية و 17 جزءا وقعت في المرحلة الرابعة و جزئين وقعت في المرحلة الخامسـة. 
و تلك خطوة تحصل على تنبؤان، التشبهات تسبّب السهولة عند الطلبة و الإختلافات تسبّب الصعوبة عند الطلبة. و هذه التنبؤ مناسب بنظرية التنبؤ التي سبق ذكرها.

وعندما يقوم بالتوضيح، وجد الباحث بعض نتيجة غير وفق لتنبؤ في الواقع. كاما في مرحلة الصفر، كانت الصعوبة وقعت بكثير عند الطلبة. و تكون مرحلة الصفرفي الرتبة الثانية كالصعوبة التي

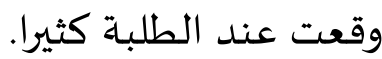

وكانت أكثر الصعوبة في المرحلة الرابعة ووجدت في الواقع بكثير ، و العنصر موجود في اللغة الثانية لا في اللغة الأولى يسبّب هذه الصعوبة. لذالك عرفنا أن عند التداخل تأثير قويّ في تعليم اللغة الثانية.

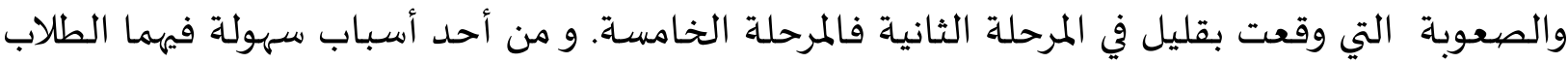
يستخدم المعجم عندما يبحث المفردات، و كان المعجم مستسهلا في بحث المفردات المناسبة. و أكّدها أيضا محاضر مادّة مهارة الكتابة بأن قد وجدت الأخطأ عندما يعبّرها الدارس. لا سيما في

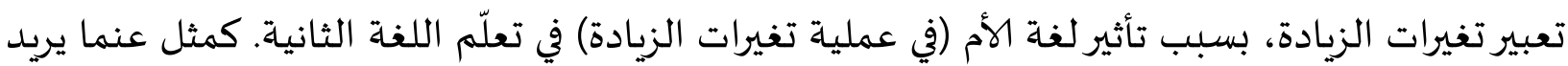
الدارس أن يعبّر فائدة الطلب. و كانوا أكثرهم لا يستطيعون أن يخترو الوزن المائ المناسب. و هذه الأخطاء أو الصعوبة سبّبتها كفاءتهم الأساسية غير جيدة و أما الطلاب الذي لا يشعر هذه

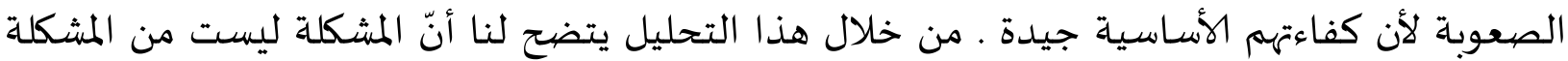
اللغوية. قبل أن ندخل في المشكلة يحسن أن أشير إلى أنّ المشكلة في تعليم اللغة العربية العالية قسمانة العان، و هما المشكلة اللغوية و المشكلة غير اللغوية.

ومن المشكلة غير اللغوية انخفاض كفائة المدرس، و انخفاض دافع التعليم، و نقصيان حصيّة الدراسية و و البيئة اللغوية. و هذه المشكلة يمكن أن يسبّب مشكلة مهارة الكتابة في فصل A. وعلى ضوء هذه الأدلة، نستطيع أن نفهم أن التغيرات الزيادة كجزء الصرف و مهارة الكتابة لا ينفصلان. لأنّ الكتابة الجيّدة هي الكتابة الصحيحة في النحو و الصرف.

\section{خلاصة}

وجوه التشبهات بين تغيرات الزيادة العربية والإندونيسية وقعت التشبهات في عدّة الأجزاء من تغيرات

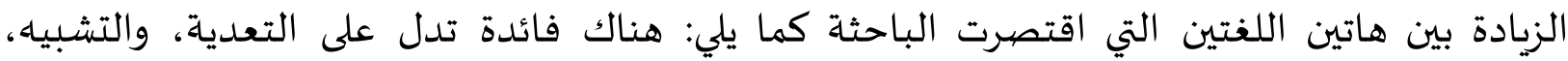

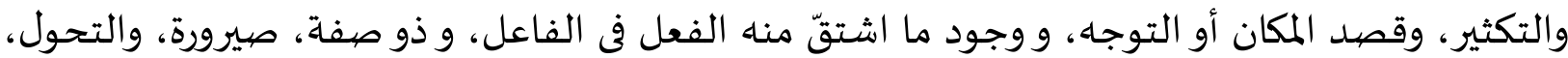

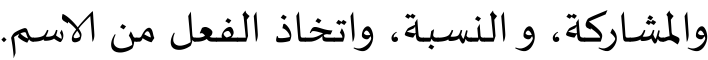

وجوه الاختلاف بين تغيرات الزيادة العربية والإندونيسية وقعت الاختلاف في عدّة الأجزاء من تغيرات الزيادة بين هاتين اللغتين التي اقتصرت الباحثة كما يلي : تعلق بالفاعل، و تعلق بازمان، و يدلّ على إزالة 
معنى الفعل عن المفعول، ويدلّ على تعريض، ويدلّ على الدعاء، ويدلّ على الطلب، ويدلّ على التصرف والاجتهاد، و يدلّ على الاختيار، ويدل على إختصار الكلمة، ويدل على التجنب، ويدل على الدخول في الزمان و المكان، يدل على الوصول الى، ويـل على مطاوعة، و يدل على التكلف، و يدل على الإتخاذ، ويدل على إضفاء صفة،، ويدل على المبالغة، ويدل على ملك، ويدل على تناول، و يدل على الإجماع، ويدل على تصيويت، ويدل على عمل بألة، و يدل على في مجموع، ويدل على استعمال الكلماة، ويدل على مبني مجهول، ويدل على وضع في المكان.

تأدية الدراسـة التقابلية في تعليم مهارة الكتابة. أولا، كتنبؤ الصعوبة في مهارة الكتابة، فيجب على المدرّس أن يفهم تغيرات الزيادة في هاتين اللغة، ويبيّن المتشابهات والإختلافات بينهما ليستطيع أن يتنبّأ السهولة والصعوبة التي سوجههها الطلاب في تدريس تغيرات الزيادة، وليستطيع أن ينقص التداخل في تدريس تغيرات الزيادة. ثانيا، كالأسـاس في صياغ التقنيق التعليمي في مهارة الكتابة، فيجب على المدرّس أن يدرّس المتشـابهات في تغيرات الزيادة مكثّفا. ويعطي تجربات مكثّفا في مهارة الكتابة، حتى ينقص التداخل في تدريس تغيرات الزيادة.

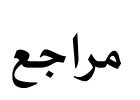

Ahmadi, Moch.Ishom. 2007. Kaifa Nurabbi Abnaa'ana Pengantar Pendidikan Islam Suatu

Tinjauan Teoritis Dan Praktis Berdasarkan Pendekatan Religi. Yogyakarta: Sj Press.

Al-Hadidi, Ali.n.d. Musykilaat Ta'lim Al-Lughah Al-'Arabiyyah Li Ghairi Al-'Arab. Kairo:

Dar al-Kitab al-' Arabi.

Alwi, Hasan. 2003. Tata Bahasa Baku Bahasa Indonesia. Jakarta: Balai Pustaka.

Arifuddin. 2010. Neuropsikolinguistik. Jakarta: Raja Grafindo Persada.

Arikunto, Suharsimi. 1997. Prosedur Penelitian Suatu Pendekatan Praktek. Jakarta: Renika Cipta.

Brown, H.Douglas. 2007. Teaching by Priciples. San Francisco: Pearson Education, Inc. Chaer, Abdul. 2015. Morfologi Bahasa Indonesia Pendekatan Proses. Jakarta: Rineka Cipta. Chesterman, Andrew. 1998. Contrastive Functional Analysis. Amsterdam: John Benjamin Publishing Campany.

Chotib, Achmad. 1976. Pedoman Pengajaran Bahasa Arab Pada PTAI. Jakarta: Proyek Pengembangan Sistim Pendidikan Agama.

Dardjowidjojo, Soenjono. 1988. Tata Bahasa Baku Bahasa Indonesia. Jakarta: Balai Pustaka.

Fahri, Ismail dan Nas Hariyati. 2007. Studi Bahasa Arab Dan Kata Serapan Bahasa Arab Dalam Bahasa Indonesia. Semarang: Rumah Indonesia.

Ma'nawi, Arief. 1999. “Ciri-Ciri Morfologis Bahasa Arab Sebagai Anggota Rumpun Bahasa Semit." Humaniora 12(3):115.

Marsono. 2011. Morfologi Bahasa Indonesia Dan Nusantara. Yogyakarta: Gadjah Mada 
University Press.

Meleong, Lexy J. 2007. Metodologi Penelitian Kualitatif. Bandung: Rosda.

Muhammad, Hamdan Ramadan. 2013. “The Role of Mosque in AchievingThe Political

Integration in The Iraqi Current Society-Analytical Study From A Social

Perspective-." Majjallah Kulliyyah al-Uluum al-Islamiyyah 7(33).

Nababan. 1983. "Peralihan Pola Perolehan Dan Penggunaan Bahasa Indonesia."

Universitas Indonesia.

Parera, Jos Daniel. 1997. Linguistik Edukasional. Jakarta: Erlangga.

Prastowo, Andi. 2011. Memahami Metode-Metode Penelitian: Suatu Tinjauan Teoritis Dan

Praktis. Yogyakarta: Ar Ruzz Media.

Ramlan, M. 2001. Morfologi Suatu Tinjauan Deskriptif. Yogyakarta: Karyono.

Sanjaya, Wina. 2008. Perencanaan Dan Desain Sistem Pembelajaran. Bandung: Kencana

Prenada Media Group.

Saville-Troike, Muriel. 2006. Intruducing Second Language Acquisition. Cambridge: UK.

Tarigan, Henry Guntur. 1992. Pengajaran Analisin Kontrastif Bahasa. Bandung: Angkasa.

$$
\begin{aligned}
& \text { الحميد, حمد مسي الدين عبد. 2005. منحة الجليل بتحقيق شـح /بن عقيل. قاهرة: مكتبة دار التراث. } \\
& \text { الراجي, عبده. 1973. التطبيق الصرفي. بيروت: دار النهضة العربية. } \\
& \text { السليم, فريد بن عبد العزيز الزامل. 1428. الخلاف التصريف و أثره الدلالي في القرآن الكسيم. القصيم: } \\
& \text { دار ابن الجوزي. } \\
& \text { الغلابينى, مصطفى .n.d. جامع الدروس العربية. بيروت. } \\
& \text { بوخدود, علي بهاء الدين. 1988. مدخل الصرفي تطبيق وتدريب في الصرف العربي. بيروت: مج. } \\
& \text { دويدري, رجاء وحيد. 2000. البحث العلهي أساسيته النظرية وممارسته العملية. دمشق: دار الفكر. } \\
& \text { شهلين, توفيق. 1980. علم اللغة العام. القاهرة: أمّ القرى. } \\
& \text { معصوم, محمد .n.d. الأمثلة التصريفية. سورابايا: مكتبة الشيخ سالم بن سعد نبهان. }
\end{aligned}
$$

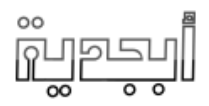

